позицию, развивает мышление, учит работать с разными источниками информации и критически подходить к действительности.

$$
* * *
$$

1. Проект ФГОС ОOO URL: https://www.preobra.ru/fgosooo19 (дата обращения: 07.02.2021).

2. Кузин Д.В. Лазукова Н.Н. Учимся приобретать и осмыслять знания. Пособие для учителя и учащихся. СПб. Корона-Принт, 1998

\title{
Серебрянцева О.Г. \\ Интерактивная технология как развивающий элемент обучения иностранному языку в вузе
}

ГБОУ ВО Московский городской педагогический университет (Россия, Москва)

doi 10.18411/gq-31-03-2021-38

idsp sciencerussia-31-03-2021-38

\section{Аннотация}

Метод case-study или метод кейсов, который можно назвать развивающим методом и интерактивной кейс-технологией, становится все более актуальным в российской образовательной системе и начинает активно применяться преподавателями иностранного языка в нелингвистических вузах, что позволяет формировать и развивать профессиональные коммуникативные навыки. Интерактивная кейс-технология вовлекает студентов в активную классную, групповую и самостоятельную работу, позволяет формировать знания, умения и навыки на основе анализа и решения реальной или смоделированной проблемной ситуации, представленной в виде случая.

Ключевые слова: кейс-стади, интерактивная технология обучения, виды технологий, анализ ситуации, виды кейсов, принятие решения.

Метод case-study (кейс-стади - от англ. "case" - случай, "study" - изучать, исследовать) или метод кейсов в настоящее время продолжает набирать популярность и актуальность в нашей стране, как развивающий инструмент обучения, позволяющий применить теоретические знания к решению практических задач.

Кейс-технология - это интерактивная технология обучения, позволяющая формировать знания, умения и навыки на основе анализа и решения реальной или смоделированной проблемной ситуации, представленной в виде кейса (случая, ситуации), который требует вовлеченности обучающегося в классную и самостоятельную работу.

Развитие навыков профессиональной коммуникации на иностранном языке является целью обучения взаимодействию специалистов в профессиональной деятельности, которые должны повышать свою коммуникативную компетентность, знать формы и методы воздействия на оппонентов или собеседников, то есть совершенствовать культуру общения [2].

В нелингвистическом вузе профессионально-ориентированное общение на иностранном языке определяется как обмен профессионально-значимой информацией, обеспечивающий взаимопонимание между партнерами по общению, то есть представителями различных профессиональных сообществ [3].

Уделяя внимание навыкам коммуникации на профессиональную тему, преподаватель нелингвистического вуза, применяющий метод case-study, имеет дополнительную возможность развивать навыки общения будущих специалистов.

Данный метод способствует развитию у учащихся самостоятельного мышления с одной стороны, и умения выслушивать и учитывать альтернативную точку зрения с 
другой стороны. С помощью этого интерактивного метода обучения, преподаватели начинают уже в начальных классах формировать и развивать аналитические и оценочные навыки обучающихся, их умение работать в команде. В младших классах ученики могут обсуждать поведение учеников, отдельные события из собственной жизни. В старших классах можно организовать дискуссию не только на тему событий собственной жизни, но и на другие абстрактные волнующие темы. В вузе можно и нужно обсуждать предметно-профессиональные ситуации. В преподавании иностранных языков данный метод эффективен, когда интересная ситуация или проблема захватывает студента своей насущностью или злободневностью, отодвигает проблему языкового барьера и позволяет легче развивать его коммуникативные навыки.

Случай (ситуация, проблема) должен соответствовать четко поставленной цели; иметь соответствующий уровень трудности; вызывать интерес у обучающихся; иметь одно или несколько решений. В описании должна присутствовать проблема или ряд проблем, подлежащих решению. Преподаватель должен знать заранее, как решить проблему, заявленную в кейсе, но не высказывать свое мнение, пока учащиеся не предложат свою идею решения предлагаемой проблемы. [5]

Основной целью кейса является обучение учащихся диагностированию, то есть анализу ситуации и принятию самостоятельного решения проблемы в процессе дискуссии. Иногда проблема не сформулирована, поэтому участники должны сами проанализировать ситуацию, найти проблему и дать рекомендации по ее решению. В этом случае учащиеся могут использовать свои накопленные по конкретной теме знания, показать свое мироощущение. Кейс-технология не ограничивается только учебным процессом, но и становится методом научного исследования, включающим научную терминологию конкретного изучаемого предмета. Поскольку данная технология включает в себя операции исследовательского процесса, аналитические процедуры, то она представляет собой разновидность исследовательской аналитической технологии коллективного обучения, так как работа проходит не только индивидуально, но и в группе (или подгруппах).

Данный метод включает в себя и синергетическую технологию (погружение группы в ситуацию, формирование эффектов умножения знания, инсайтного озарения, обмена открытиями и т.п.), а также интегрирует в себе технологии развивающего обучения, формирующего личностные качества обучаемых [1].

Метод кейсов также можно назвать разновидностью проектной технологии. Но в отличие от темы кейса тема обучающей проектной технологии может быть более широкой и предполагает заранее подготовленное индивидуальное или коллективное исследование.

Существует несколько видов кейсов: практические, обучающие, научноисследовательские. Наиболее эффективными в обучении представляются небольшие по объему кейсы, которые можно предложить и обсудить прямо на уроке. Такой кейс состоит из четырех частей: история (случай, ситуация), вопросы для выяснения полноты ее понимания (обращается внимание учеников на конкретную информацию в тексте кейса), решения (рекомендации), высказанные участниками в результате обсуждения, оценка активности каждого участника.

Преподаватель может заранее подготовить учащихся по отдельной теме, затем применяет метод кейс-стади в завершение данной темы на последнем занятии. Преподаватель может также предъявлять и сразу закреплять новый материал на одном занятии, устраняя монотонность изложения материала традиционным способом. Чтобы самостоятельно составить кейс, преподаватель может обратиться к источникам художественной, публицистической, специальной литературы, событиям из жизни группы, поскольку в учебной литературе в настоящее время недостаточно учебных пособий и учебников, содержащих кейсы на интересующую тему. В то же время сейчас 
имеется достаточно специальной литературы по созданию кейсов (руководства). Для придания кейсам научной строгости, можно использовать статистические материалы. Из Интернета преподаватель может брать подтвержденные материалы, опирающиеся на известные источники [4].

После дискуссии преподаватель обязательно должен оценить деятельность каждого участника, повышая тем самым мотивацию к изучению предмета. Результатом применения метода в вузе являются не только знания, но и навыки профессиональной деятельности.

Подводя итог вышесказанному, можно сказать, что преимуществом метода кейсов является возможность оптимально сочетать теорию и практику в обучении. Наличие в структуре кейс-метода дискуссий и аргументации тренирует участников, развивает их коммуникативные навыки, то есть учит соблюдению норм и правил общения, учит четко выражать свои мысли.

Метод кейс-технологии обеспечивает освоение теории и овладение навыками практического использования материала; воздействует на профессионализацию обучающихся; формирует их интерес и позитивную мотивацию по отношению к учебе. Преподаватель становится фасилитатором, то есть помощником обучающихся в течение всего процесса обучения, решает и не допускает конфликты, создает обстановку сотрудничества. Не навязывая свое мнение, он добивается активного участия всех, присутствующих на занятии.

Таким образом, педагогический потенциал кейс-метода гораздо эффективнее, чем традиционные методы обучения, повышает качество образования. Практически, данный метод универсален, так как его можно использовать в преподавании любого предмета, что и происходит в настоящее время в нашем образовании.

$$
* * *
$$

1. Земскова А. С. Использование кейс-метода в образовательном процессе // Совет ректоров. - М.: 2008. - № 8. - С. 12-16.

2. Серебрянцева О.Г. Метод кейсов как развивающий элемент обучения в педагогическом учреждении - Наука России: Цели и задачи. Сборник научных трудов по материалам XXIII международной научно-практической конференции 10 октября 2020 г. Изд. НИЦ «Л-Журнал». 2020. -68 c.

3. Серебрянцева О.Г. Метод кейс-стади как средство развития коммуникативной компетентности в нелингвистическом вузе. - Международный научно-исследовательский журнал / Internatinal research journal. - Екатеринбург. - "А-принт", 2020 - № 2 (92), часть 2.

4. Федоринова 3.В. Использование case-study в организации образовательной деятельности (на примере преподавания английского языка) // Филол. науки. Вопр. теории и практики. - Тамбов: Изд-во «Грамота», 2010. - No. 1(5). - С. 210-215.

5. http://www.partnerstvo.nj/modules.php?name=Content\&pa=showpage \&pid=22

\section{Сицинский Г.Ю. \\ Реализация национального проекта «Образование» в условиях пандемии: характеристики и проблемы}

НОЧУ ВО «Московский финансово-промышленный университет «СИНЕРГИЯ» (Россия, Москва)

doi 10.18411/gq-31-03-2021-39

idsp sciencerussia-31-03-2021-39

\section{Аннотация}

В настоящей статье автор анализирует исполнение национального проекта «Образование» в сложных эпидемиологических условиях. Автор рассматривает финансовый аспект, структурные изменения национального проекта. Проводится анализ проблем, которые возникли во время пандемии, в первую очередь - проблему дистанционного обучения, внедрения современных цифровых технологий. В статье 